\title{
SOME CONSIDERATIONS ON BIBLE TRANSLATION AS COMPLEX PROCESS
}

\author{
J.G. van der Watt ${ }^{1} \&$ Y. Kruger ${ }^{2}$
}

\begin{abstract}
It is argued that translation is a complex process: meaning is "created" by decoding the source text on several levels (for instance, grammatical; structural; literary; and socio-cultural levels). This "meaning" must then be encoded into the target language by means of the linguistic, literary, and cultural conventions of the target language. These different aspects (grammar, structure, etc.) combine in an interactive process and result in meaning. Atomisation or compartmentalisation of the various aspects distorts communication. It is also argued that it should be assumed that what can be said in one language can be said in (translated into) another language, but not necessarily by combining the relevant linguistic, literary and cultural aspects in the target language in the same way as they were combined in the source language. This is because languages do not overlap in their use of words, structures, genres, and social conventions. This inevitably leads to the realisation that a translation could and would never be an exact "copy" of the original.
\end{abstract}

\section{INTRODUCTION}

The definition of "translation" adopted by a particular translator will have a critical impact on the course taken by the translation process. ${ }^{3}$ It is this preconceived idea (definition) of what a translation entails that determines

1 Prof. Jan G. van der Watt, Department of New Testament, Faculty of Theology, University of Pretoria, Pretoria.

2 Yolanda Kruger, Research Assistant, Department of New Testament, Faculty of Theology, University of Pretoria, Pretoria.

3 See Naudé (2001:177-194) for a description of the different approaches to translation and how these approaches affect the "end product". Translation can be defined in several ways. One, for instance: a translation should

convey and reflect the vocabulary terms and grammatical forms of the original writings within the corresponding document in the receptor language." (www.auburn.edu/ allenkc).

This definition will lead to a literal translation where the form of the original language will dominate. Other definitions will focus more on the meaning in the target language. For example: a translator should discover the meaning in the source language and then reformulate that meaning in the language tools of the target language in a clear and natural way (Larson 1984:5-6). Reiss \& 
the consequent actions of the translator. ${ }^{4}$ If (s)he, for some reason, regards translation as something that should be done word-for-word, (s)he will approach and translate the text in that particular way. If the translator, however, is more interested in the meaning of the text, a meaning based translation ${ }^{5}$ will result.

In this article, emphasis is placed on the influence of the complexity of language on the process of Bible translation. ${ }^{6}$ This complexity should have an influence on the way translators view and in the end define their activity.

\section{TRANSLATION AS COMPLEX PROCESS OF DECODING $^{7}$ AND ENCODING $^{8}$ MEANING}

Translation is a complex process:" meaning is "created" by decoding the source text on several levels (for instance, grammatical, structural, literary and socio-cultural le-

Vermeer (1984) and Nord (1991) focus on the influence of the translation on the receivers. The satisfaction and requirements of the receivers of the translation should be met, rather than rendering the source text as closely as possible, even if it means laying a different emphasis in the translation or leaving out/ adding material to the translation.

4 According to Comfort (1989:31)

we can assume that most translators have desired to achieve dynamic equivalence in their translation, but ever since the time of Jerome, there has been a debate over what is the best method to accomplish this: the word-for-word approach or the sense-for-sense.

5 There are many different ways a meaning-based translation can be made. It ranges from an approach that emphasises the meaning but still tries to stay as close as possible to the form of the original text, to an absolutely free translation that makes no effort to physically retain the original form and focuses completely on the satisfaction of the receptor (Reiss \& Vermeer 1984; Nord 1991).

6 Due to the nature and restrictions of this article, these complexities will not be discussed in minute detail. The emphasis lies more on the total picture than on the smaller detail. We acknowledge that the picture is far more complex than is presented here. See Whang (1999:47-49) on the complexity of translation.

7 Decoding is "that operation by which a receptor interprets a discourse and understands its message" (Nida \& Taber 1982:199).

8 Encoding is "that operation by which a sender plans a message and composes a discourse to convey it" (Nida \& Taber 1982:200).

9 Nida (1991:5) quotes T. A. Richards as having said that translating is "probably the most complex type of event yet produced in the evolution of the cosmos" and yet it ironically seems completely natural for bilinguals and children. 
vels). This "meaning" must then be encoded into the target language by means of the linguistic, literary, and cultural conventions of the target language. ${ }^{10}$ These different aspects (grammar, ${ }^{11}$ structure, etc.) combine in an interactive process and result in meaning. Atomisation or compartmentalisation of the various aspects distorts communication.

In meaning-based translations it is assumed that the translator should establish the meaning of the source text, as far as that is possible, in order to "translate" that into the target language. ${ }^{12}$ However, establishing meaning is a complex process. There are different types of meaning (denotative, connotative, associative, etc.) ${ }^{13}$ different levels of meaning (primary, secondary, etc.), multiple ways to interpret words, rhetorical devices, grammatical or semantic structures, etc. In the end, the translator is confronted with a labyrinth of possibilities and choices.

\subsection{Constituent elements}

Without going into minute detail, the following aspects may be mentioned as constituent elements in interpreting a text.

1) The construction and semantics of words (including phonology and lexicography).

2) The construction of sentences (syntax ${ }^{14}$ and some stylistic elements, such as figurative language, metaphors, idioms, symbolism, sarcasm, irony,

10 According to Nida (1991:10)

the actual process of translating is perhaps best described as a technology which employs the insights and principles of a number of branches of behavioral science in order to accomplish its goal of effective interlingual communication.

11 According to Baker (1992:83)

grammar is the set of rules which determine the way in which units such as words and phrases can be combined in a language and the kind of information which has to be made regularly explicit in utterances.

12 Whether this is possible at all, is expressed in concerns by proponents of deconstructionalism or post-modernism, "intentional fallacy", the role of the reader in creating meaning, etc. There is no time or space to go into this theoretical debate here, but there are some real concerns to take note of.

13 See Nida \& Taber (1982:56-90, 91-98, 199, 205).

14 Hendriks (1998:66-68) illustrates the impact on different translations when the syntax is interpreted in different ways. 
etc. are relevant). Words get their function and meaning inter alia within sentence structures, which might also play a role in determining the rhetorical nature of the text. ${ }^{15}$

3) The structure of paragraphs (including the analysis of structures and discourses). ${ }^{16}$

Although the above-mentioned elements are also socio-culturally determined and reflect cultural convention, ${ }^{17}$ they can be more or less identified in and through the physical text itself. Two other elements that form part of constituting meaning deserve mention. However, implicit knowledge is usually necessary to identify these two elements:

4) The genres ${ }^{18}$ of texts (including the use of micro, meso, and macro genres). ${ }^{19}$ Realising that a piece of communication is a joke and not a scientific statement might make all the difference in the process of determining meaning. ${ }^{20}$

15 Bastiaens (1998:153) indicates that translation should use the sentence (and not words) as point of orientation. The sentence again forms part of the larger whole.

16 See Wendland \& Louw $(1993: 4,11)$ on the importance of paragraphing in the reading and interpretation process. Meaning should not be looked for in analysing words or even sentences, but meaning is a product of the inter-relatedness of the elements. When studying words, it should always be done in the light of their position and function within their larger linguistic and literary context.

17 The ancient texts were not handed down with clear indications of sentences or paragraphs. On the contrary, the text was written in long continuing lines. Paragraph breaks are made by looking at the grammar, particles which indicate brakes, or content. To divide texts into paragraphs or sentences is therefore part of the process of interpretation.

18 Genres are of course scientific constructions that are used to classify literature. Genres do not present objective or absolute criteria. Barton (1984:32) formulates it this way:

a conventional pattern, recognizable by certain formal criteria (style, shape, tone, particular syntactic or even grammatical structures, recurring formulaic patterns), which is used in a particular society in social contexts which are governed by certain formal conventions.

19 In a letter, the macro-genre would be "letter". In the letter, diverse other genres like poems, jokes, etc. might be used. These can be called meso-genres since they are used within the framework of a larger genre, the letter. On the lowest level one might find comparisons, metaphors, etc. which one might call micro-genres.

20 Nord (1997:53) also emphasises the point:

Genre conventions are the result of the standardization of communication practices. As certain kinds of texts are used repeatedly in 
5) The socio-cultural and bistorical ecology: This element deals with knowledge of the world, society, geography, history, etc. of the particular community to whom the source document was written. Communication (statements, arguments, rhetoric, content, etc.) is usually embedded in a particular socio-cultural and historical milieu. ${ }^{21}$ This type of knowledge is often implicit and not spelt out in the text itself.

Usually the reader does not find reference in the text itself to the type of genre (in a letter one usually does not read that it is a "letter") or to the characteristics of that particular genre. It should be deduced from the text. If mention is made of socio-ecological elements such as "stadia" or "pieces of silver", the reference is usually assumed. The same applies to certain social conventions such as friendship, or being a procurator or tax collector. It is assumed that the reader will know what is intended due to the implicit knowledge of both author and reader. However, the contribution of the above two aspects to the proper understanding of a text is crucial and should be taken into account by translators.

Interaction between the above mentioned elements during the process of reading contributes to the creation of meaning. It is a spiral-like process that entails a constant interaction between the elements, resulting in the deepening of meaning. Reading does not only involve isolated words or isolated sentences, but words and sentences which interact to result in larger "units" of communication. ${ }^{22}$ Schematically this interactive process might

certain situations with more or less the same function ... these texts acquire conventional forms. Genre conventions and norms thus play an important role in both text production (because authors have to comply with the conventions if they want to carry out their communicative intentions) and text reception (because receivers must infer the author's intentions from the conventional form of the text).

21 Gutt (1988:34) emphasises the importance of socio-cultural knowledge.

We should make clear to ourselves that some inadequacies in our linguistic knowledge of the receptor language, e.g., about some morphological rules of the language, will probably be far less detrimental to our communication efforts than an inadequate knowledge of the religious beliefs, concerns, and overt and covert spiritual needs of the receptor language people; misjudgment in this area will almost certainly do considerable damage to our communication efforts.

22 Reading is an interactive movement between the individual parts and the whole. Noorda et al. (1998:206-208) support the idea of the Italian philosopher, Croce, that simply translating words or sentences does not convey meaning, and 
be illustrated as follows. The thick arrow indicates the movement in the reading process - it starts with words (from the "bottom") to paragraphs (top) within the context of genre and socio-cultural ecology and then moves back, so that the words/sentences are understood in the light of the larger process. It represents a spiral movement:

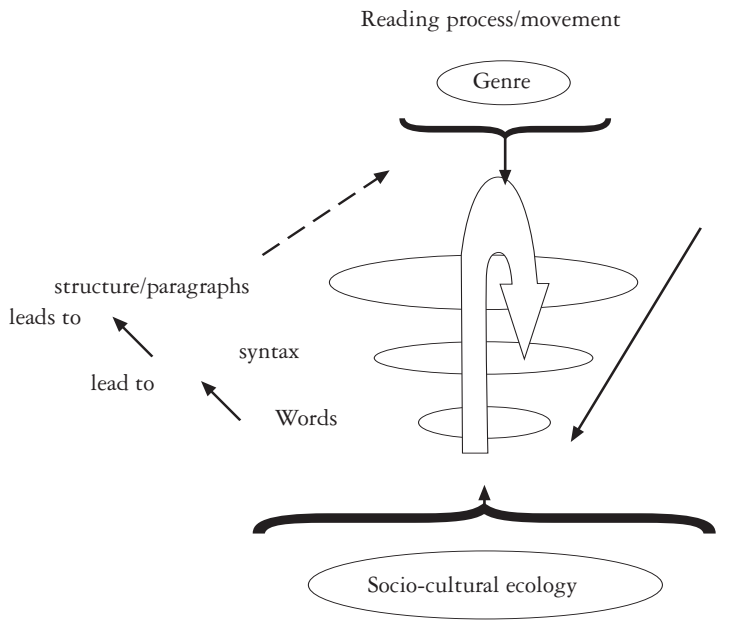

Like different threads form part of a string, all the above-mentioned elements form part of the complex process of reading a text. ${ }^{23}$ The moment one speaks of "meaning", it must be accepted that all these elements should be read in interactive combination. Since meaning is generated through such a complex process, ${ }^{24}$ it seems necessary that the translator be conscious of the different steps taken to "unlock" the various contributing factors in this interactive process. ${ }^{25}$

is not trustworthy. The reason is that words or even grammatical constructions do not play the only role in constituting meaning. These words or grammatical constructions get their functional meaning within the larger communicative ecology. "Kortom, de context is doorslaggevend" (Noorda et al. 1998:207).

23 De Kruijf (1998:162) refers to the theories of some philosophers (Schleiermacher, Gadamer) in this regard. See also De Kruijf (1998:165).

24 Noorda et al. (1998:206) also underline the complexity of the translation process, since bringing together two complex systems, inevitably provides the translator with an "astronomische hoeveelheid variabelen".

25 Peacock (2000:201) refers to the different areas a translator must master and rightly remarks: "The task that faces the Bible translator is enormous". 
The interpretation and translation of a particular text must, therefore, be systematic and well reasoned, ${ }^{26}$ taking into account relative contributions of all these elements. In this vein Noorda et al. (1998:207) describe the procedure followed by Dutch translators in their new Bible translation. The text is first interpreted as a whole, and then divided into smaller passages. The translator must decide which element or aspects of the text (form, content, etc.) carries most weight in a particular section and divide and treat the passage accordingly. Translation is a constant process of making decisions involving analyses and syntheses.

How deep should the translator be involved in the interactive process? Up to now it was assumed that the translator should partake in the whole process. There are, however, views that the translator should stick to the level of "codes" only — whatever that might mean — and not move beyond that. ${ }^{27} \mathrm{~A}$ basic question is, therefore, where exactly translators should "get out" of the "process". Should they only deal with the first two levels (the word and sentence level, which might be regarded as only working with the "codes"); should they involve themselves with the paragraph level; or should they also give attention to the genre and eventually to the sociocultural ecology in the process of translating a text? ${ }^{28}$

We are of the opinion that the whole process should be taken into account when translating a text. If it is true, as was argued above, that the process of grasping the meaning of a text includes all the different elements, it makes sense for translators to keep them all in mind. To limit

26 Though this might not seem like an important point, it is indeed. It seems as if translations are often made based on "gut feeling" or with emphasis on the particular interests or strengths of the translator (for instance, a strong linguist will emphasise linguistic aspects, while a person with social interests will choose words that reflect his/her particular interest). Care is needed to ensure a proper balance in the translation.

27 Van Iersel (1998:172-173) limits the involvement of the translator. He distinguishes between two levels, namely the level of codes, to which he limits the activity of the translator, and the level of the metatext, where the exegete is active. A translator's task is to make the codes of the source text accessible to the receiver of the target text. Van Iersel defines "codes" in a restricted way that should be questioned. See also Naudé (2001:180).

28 De Kruijf (1998:163) warns against reading texts without considering their contexts. Obviously, these contexts do not only include the original context in which the text was written, but also the context of the current reader/receptor. In Bible translation a balance between the original framework of the text and its actuality should be maintained. 
themselves to two or three elements can result in bisecting the process of generating meaning. ${ }^{29}$

A few examples will illustrate the point:

1) Considering only the first two elements (the construction of words and sentences) will result in the translator using a lexicon to translate, for

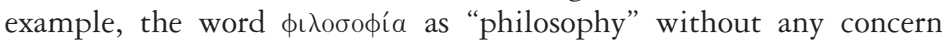
whether the reader in the target language will know what was intend-

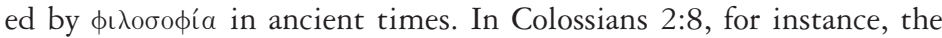
meaning of $\phi \iota \lambda \circ \sigma \circ \phi i ́ a$ refers to the motivating grounds for a person's actions, dealing with issues of his or her practical existence. This nuance can only be appreciated when taking the context, ${ }^{30}$ as well as the ancient socio-cultural conventions, seriously. ${ }^{31} \mathrm{~A}$ word-for-word translator will usually make no effort to interpret the stylistic and other structural features of the text, but will simply transfer them into the target language. A chiasm is simply presented as a chiasm, without asking whether the reader of the target language will be able to interpret a chiasm for what it intends to communicate in the source language. This type of approach has a mechanical side to it that inhibits the process of understanding.

2) The paradigmatic cohesion of a text is also of importance. An adequate translation must reflect the internal cohesion on syntactic and thematic levels. ${ }^{32}$ However, care should be taken not to divide paragraphs in ways that would predispose meaning by severing sentences that belong together. Even word-for-word translations usually have paragraph divi-

29 Sterk (1994:130-131) describes the limited meaning that results from a narrow approach to translation:

Literal translation fails because it is largely insensitive to the difference in the way the form/meaning interaction takes place in the source and the way it operates in the receptor languages.

On the other hand:

... functional equivalence has a problem too: in it we try to dissect a source text and separate form from message or meaning. We then transfer into the idiom of the receptor language what we consider to be the message: and we leave the forms of the source text behind, so to speak.

30 As Baker (1992:6) points out: "Translating words and phrases out of context is certainly a futile exercise."

31 This explains the expression that a word finds its meaning within a context.

32 See Hendriks (1998:75) and Beentjes (1998:77-84). 
sions, which is, off course, an important way translators influence text reception based on their initial interpretation. Take the example of Ephesians 5:21-22ff. The NIV (and RSV) print it as follows:

21 Submit to one another out of reverence for Christ. Wives and Husbands

22 Wives, submit to your husbands as to the Lord...

In the New Afrikaans translation it is presented as follows:

\section{Man en vrou}

21 Wees uit eerbied vir Christus aan mekaar onderdanig.

22 Vrouens, wees aan julle mans onderdanig, net soos julle aan die Here onderdanig is.....

The implications of the difference in division as well as heading are evident. In the first example, submission has to do with one's every day life (the previous context). In the second example, submission should be interpreted in direct relation to marriage, which makes a major difference to the interpretation of the section on marriage. Some commentators have argued that reading verse 21 together with what follows was a main impetus for women's emancipation. Such an utterance on man and wife was quite revolutionary for ancient times. The moral of the story is that although all translations divide the text into paragraphs, it should be done with great care and sensitivity. ${ }^{33}$ Paragraph divisions (and their headings) have a definite influence on the process of interpretation, as is indicated above. ${ }^{34}$

3) Being familiar with the genre is also of importance. Take the following sentence: "Honey, are we eating out tonight? I do not smell anything burning." If this sentence is uttered as a joke, the effect will be laughter. If it is uttered within the genre of serious talk, the effect might be

33 According to Wendland \& Louw (1993:4)

... a quick look at paragraphing in most Bible translations ... shows how this has usually been done on the basis of only a broad impressionistic understanding of larger chunks of the message. Proper discourse analysis seems hardly to have had any effect on the decisions, and section headings seem to follow long established traditions in recognizing certain familiar stretches as pericopes.

34 As with the example of Eph. 5:21-22ff, Wendland \& Louw (1993:10-11) point out that in selecting evidence for doctrinal issues proper formatting (paragraphing and section headings) is of utmost importance. 
divorce or serious injury. Genre contributes substantially to the semantic function and effect of the text. As language in general, genre is determined by socio-linguistic convention and not necessarily explicitly mentioned in the text. The hymns in the New Testament usually do not mention that they are hymns. ${ }^{35}$ Nevertheless, indications of the genre may guide the reader by creating expectations (with the words: "Once upon a time", for instance) or by the way in which information is introduced and handled (a joke and a hymn will present information differently). Misreading the genre can result in serious misinterpretations. The history of parable interpretation is a point in case. ${ }^{36}$

How can the translator help the reader of the target language to grasp the functionality of a genre in a particular text? Many translations print hymns in short phrases, presenting them as we know poetry. This is a possible solution. But what about the other genre types? Would it be possible to change the form of the ancient letter in the New Testament to the form of letters today, thereby starting with "Dear..." and ending with "Best wishes, Paul"? Will this convey the idea of a letter or will it lower the historical character of the particular document?

These problems need more consideration, since forms do not overlap between different languages. Footnotes or other methods of enriching the text may be of help. In some cases, like with parables and miracles, the reader is told what the genre is ${ }^{37}$ though not how to interpret it. ${ }^{38}$

4) This brings us to the question of socio-cultural ecology..$^{39}$ References in the text that reflect the socio-cultural ecology can roughly be distinguished as explicit and implicit references. Explicit references are, for example, to places like Jerusalem, to time (sixth hour), currency (pieces of silver), measuring distance, weight or contents and clothing, as well as references to social groups, such as the Pharisees. Present-day readers will immediately realise that these aspects do not form part of their

35 See Phil. 2:5-11; Col. 1:15-20.

36 See Van der Watt (1995:ad loc.).

37 See, for instance, Mt. 13:3; Jn. 2:11

38 As Nord (1997:54) points out:

Since genre conventions are mostly culture-specific, they play an important role in functional translation. If a target text is to be acceptable as representative of a target-culture genre, the translator has to be familiar with the conventions that the target text is to conform to. Further ... the translator has to be familiar with the conventions of the genre to which the text belongs.

39 See Weren (1998:109-110) for a discussion of this problem. 
own socio-cultural ecology. Many modern translations share the policy that certain elements, such as pieces of silver, stadia, etc., should be replaced with equivalent words known to the source text readers. References to physical locations or pieces of clothing are usually not replaced. Some elements of explicit references are therefore simply translated word-for-word while others are replaced with some sort of equivalent. ${ }^{40}$ Literal translation seems to be a good option for translating location and geographical areas. As far as the other aspects, such as money or distance, are concerned the option of footnotes or present-day equivalents are appealing.

What about implicit socio-cultural references in texts? The Bible was written two thousand years ago in a foreign language and foreign cultural ecology. People simply did things differently in those days. People's treatment of one another, their view on gender and status, money, children, and society as a whole, differed in more than one way from our twenty-first century perspectives. These ancient socio-cultural views are, however, encoded into the Biblical text. If it is simply replaced in a literal way, the present-day readers will not be able to grasp what is intended, since they do not share the same socio-cultural information. ${ }^{41}$ This may be illustrated by the parable of the marriage feast (Matt. 22:1-14). Why was it necessary for the king to send his servants (verse 3); why did the king kill those who did not attend (verse 7); considering the open invitation, why did the king throw out the person without a wedding garment (verse 13)? All these aspects stand in tension with present-day practices, but they have plausible explanations in the light of ancient socio-ecology. They represent implicit socio-cultural conventions, which cannot be ignored when translating a text.

40 Finding equivalents is based on analogy, which means that there will be points of similarity, as well as points of difference. It is no waterproof approach. Baker (1992:6) also points out that

equivalence can usually be obtained to some extent, it is influenced by a variety of linguistic and cultural factors and is therefore always relative.

41 Gutt (1988:30), in defending relevance theory, writes:

Considering now that in Bible translation we are taking the same texts that were written for audiences two thousand or more years ago in a particular corner of the world and presenting them to audiences today ... without content adaptation, it should not come as a surprise at all that we encounter not only marginal but serious communication problems. 
The same applies to stylistic features such as comparisons or metaphors. Take, for example, a metaphor like "I am the bread of life" in John 6:39. The meaning seems quite evident. However, if you have never spent some time in the desert without food, the metaphor will not have the required emotive impact. To go even further, if you are not familiar with the role of bread in ancient meals, you will have to be satisfied with a limited understanding. Let us take a comparison such as: "You are my protection like a rock." How does a rock protect you? Knowledge of the geography of Palestine, as well as of travelling in this country and neighbouring areas, is needed to make any sense of the comparison. Symbols like "I am the vine" (John 15:1) or "I am the good shepherd" (John 10:11) are based on well-known Old Testament symbols. John took up these symbols and adapted them. If the reader is unaware of the symbolic background of these references in John 10 and 15 , understanding will be limited.

\subsection{Translating implicit information}

But how far should a translator go in opening up the socio-cultural or stylistic features to the present-day reader? Strictly speaking, these implicit elements are part of the original communication process. The original author did not spell it out, since he or she took it for granted that the readers would be familiar with these elements. ${ }^{42}$ To be able to understand what he means implies that one has access to the implicit information. People who are not familiar with them should be provided with more information in order to understand the text of the New Testament in the same way as the original readers. ${ }^{43}$ This is important, especially in the light of the remark by Camery-Hoggatt (1995:84):

An act of reading is valid to the extent that it fills in the gaps of the text with the schemas that were operative for the culture in which the text was composed. ${ }^{44}$

42 Weren (1998:109) wants to retain the historical references in the translated text. This will prevent anachronisms and will also retain the cultural-historical flavour of the text.

43 Van der Stichele (1998:147) has shown that in freer translations it is easier to change the translation to be more inclusive. This is indeed the implication of accepting a meaning based and cultural sensitive translation theory.

44 According to Winckler \& Van der Merwe (1993:55)

as in the best available knowledge of Biblical Hebrew and Greek, so in the best available knowledge of extra linguistic matters, translators have to expect to be often confronted with big gaps. In such 
Again, the question is how this should be done in a translation. De Kruijf (1998:166) is of opinion that there should at least be indications in the text that help the reader to "discover" the implicit. It could be done by using images, words or syntax with double meaning, or by leaving "open spaces" in the text. The reader will be prompted to reflect on the text. It could also be done in more explicit ways, by means of extended sentences in the translation or footnotes, for example. One should, however, take care not to "over-translate" by saying more than was initially intended.

Does the translator have the comprehensive task of not only translating words, sentences, paragraphs, or stylistic features, but also conveying the atmosphere, and contribution of the original context to the communication dynamics, as far as that is possible? Again, this question must be answered with care. Sentences get meaning within particular contexts. If the translator is aiming at conveying meaning, the context, within which that meaning will be realised, must be taken seriously. One can also ask whether it is the task of the translator to convey some of the implicit information, shared by the ancient author and receivers, in the translation to help the presentday reader grasp the meaning.

This issue is of special importance if translation is defined as conveying meaning. In that case, all aspects in the process of meaning creation should be taken seriously. The options vary. One can either use footnotes or simply expand the text by explaining the meaning of a particular word through paraphrase in order to render the meaning as clear as possible in the source language. ${ }^{45}$ Translation implies interpretation, ${ }^{46}$ which means that the translator aims to "retell" what the original text offers. This "retelling" should come as close as possible to the original process of communication.

cases they may have to make do with the hypothetical constructions which seem best supported by the available data.

45 This is also emphasised by Noorda et al. (1998:209).

46 According to Omanson (1988:27)

translation and interpretation are interrelated and not mutually exclusive tasks. A translation may reflect good interpretation or bad interpretation, but it cannot reflect no interpretation. 


\section{TRANSLATION IMPLIES LOOKING FOR THE PROPER "MIXTURE" OF LANGUAGE CODES IN THE TARGET LANGUAGE.}

It is assumed that what can be said in one language can be said in (translated into) another language, but not necessarily by combining the relevant linguistic, literary and cultural aspects in the target language in the same way as it was combined in the source language. This is because languages do not overlap in their use of words, ${ }^{47}$ structures, genres, and social conventions. This inevitably leads to the realisation that a translation could and would never be an exact "copy" of the original.

\subsection{Different languages use different "mixtures"}

Through and in the process of interactive combination of linguistic, literary, and socio-cultural elements, meaning is created. Translation involves decoding this interactive process in the source language and then encoding it in the target language in such a way that the meaning in both cases corresponds as closely as possible. ${ }^{48}$ We have already shown how words are combined within syntagmatic and paradigmatic structures, ${ }^{49}$ while certain stylistic, rhetorical and socio-cultural features also influence the creation of meaning.

The manner in which the elements, that form part of the process of creating meaning, combine, differs from language to language. Different languages "mix meaning" differently. Neither the meaning of words and the structure of language, nor the conventions regarding genre, rhetoric, etc., overlap between languages. ${ }^{50}$ Even the method of combining the respective aspects into sentences or paragraphs does not overlap between languages, but various combinations in different languages might well lead to the same meaning. All the elements, and not only words, that contribute to meaning should be taken into account as part of a coherent process. Schematically it can be viewed as follows:

47 Baker (1992:11) maintains that "there is no one-to-one correspondence between orthographic words and elements of meaning within or across languages."

48 Weren (1998:114) sees this as a basic principle of translation.

49 See Egger (1996:105-106) on syntagmatic and paradigmatic relationships.

50 Noorda et al. (1998:204-205) point out that in the Dutch translation distinction is made between aspects that are typical of the Greek or Hebrew. These aspects are called characteristics of that particular language and should be replaced with language signs that are characteristic of the receptor language. Other aspects are typical of the text itself. They should not be replaced. In this way, they claim, the stylistic characteristics of the different books will be preserved. This distinction is, however, not without problems. 
Greek

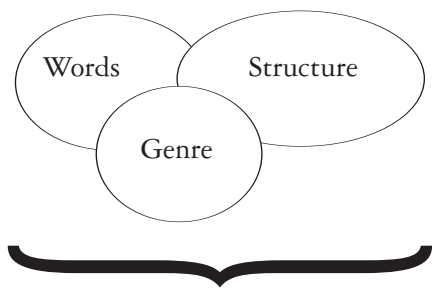

Meaning
Afrikaans
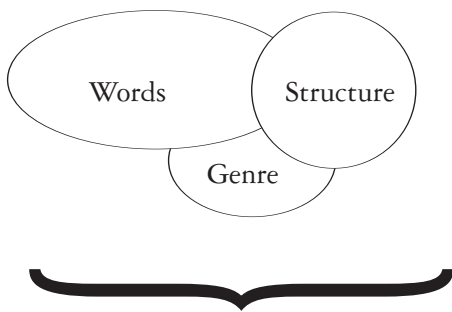

same

$=$

Meaning

In the light of the above, translations with a word-for-word tendency are problematic. Their supporters feel that structural elements, like chiasm and parallelism, as well as specific literary forms, like poetry, are only translated properly when these elements are "reproduced" in the target language exactly as they were used in the source language. Words should be replaced by lexical equivalents ${ }^{51}$ and the number of words be kept as close as possible to the original. The translation should follow the structural and grammatical contours prescribed by the source text. The implicit assumption of this approach is that words, repetition, parallelism, chiasms, etc. have the same function in different languages. This is, however, not the case. Words, structures, literary and socio-cultural conventions do not overlap in languages and beg for a different approach. In a sense, a "new mixture" and therefore a new text will result. A translation can never exhaust the original. On the other hand, the translation will inevitably add a measure of new meaning to the original. ${ }^{52}$

51 Acknowledging that literal translations can be functional in, for instance, compiling a synopsis, we take note of Van Zyl's (1999:467) translation strategy in preparing a synopsis: he aims to stay as close as possible to the Greek syntax and idiom, and aims to replace the Greek words with Afrikaans equivalents as far as that is possible.

52 See Naudé (2001:181). According to Peacock (2000:202), Sterk argues that translation is re-creation and one should look at

the inner form-meaning dynamics present in the source text, rather than a constraint found in the receptor language audience or its needs.

The translations should take place according to the constraints of the text. 
It can indeed be asked whether a translation, that presents the reader with a $100 \%$ exact reproduction of the original meaning, is possible. This does not seem possible. ${ }^{53}$ There are so many variables (forming part of such a complex process of "mixing" the different elements) that realise meaning, that an exact "matched mix" barely seems possible. Noorda et al. (1998:211) also refer to the fact that the contents may vary according to the interpretation given to them. Add to this the multiple ways in which the different elements can be "mixed" and the relative influence of each of these elements in the production of meaning, and the complexity of the process of reproducing meaning becomes evident.

To call a translation "trustworthy" does not imply that it is exact or precise in every aspect. Weren (1998:97) correctly remarks that a translation can only be a "benaderde weergawe" (approximate rendering) of what you find in the original. A complete semantic reproduction is not possible. However, the functional, hierarchically important elements of the source texts should at least be reflected in the translation for it to be called "trustworthy". ${ }^{54}$

Let us look at a few examples of what was stated above:

Would it be enough to translate the word $\phi \iota \lambda \epsilon_{\omega}$ with "love" in English? From the perspective of reproducing exact meaning, this might be problematic. Since words do not semantically overlap in different languages, new and other words should be used to communicate the comparable message. In the target reader's interpretation process, "love" must be filled with meaning (which might range from sexual attraction to deep spiritual involvement). In the ancient Greek world, loyalty and responsibility towards your own group, and not necessarily emotions, were some of the basic semantic characteristics of $\phi \iota \lambda \epsilon^{\epsilon} \omega$. To translate $\phi \iota \lambda \epsilon^{\prime} \omega$ with "love" might be the wrong choice in certain contexts. The translator should not create "more and clearer meaning", neither obscure meaning because (s)he wants to limit (her)himself to the form of the original. ${ }^{55}$ The translator must seek to make out what the original person would have understood and endeavour to reproduce nothing less and nothing more.

Some assume that an Afrikaans-speaking person will interpret chiasm as stylistic feature in the same way an ancient Greek speaker does. This is not true. In Afrikaans, a chiastic construction does not have the same se-

53 "Translations will always be imperfect, for a variety of reasons" (Omanson 1988:28).

54 This is pointed out by Noorda et al. (1998:211).

55 See Weren (1998:97). 
mantic impact as in Greek. Chiasms are used for emphasis in the Greek language. If an Afrikaans speaker does not recognise the chiasm, the communication of emphasis will be lost. The following chiasm in Greek: "The sun shines and it is hot, how hot is it in the sun" will be translated into Afrikaans as: "Dit is regtig baie warm in die son" "It is really, really hot in the sun") or "Weet jy wat, dit is warm in die son" ("You know what, it is hot in the sun"). The words are not repeated (chiastically) in Afrikaans, but a phrase communicates the emphasis the chiasm conveys. The sentences differ in form, but in meaning, they come close. To preserve the emphasis, the Afrikaans person will have to make a different "mix" of elements. ${ }^{56}$

It goes even further. If a comparison is made between the language structures of Afrikaans and those of Greek, the differences are significant. Afrikaans communicates in a more linear fashion; the sentences are shorter than in Greek and you do not really have the possibility or organising sentence structures to the extent that it can be done in Greek. The Greek language has long subordinate sentences, ${ }^{57}$ while Afrikaans prefers shorter sentences. It is possible to build a sentence in various ways in the Greek language. Using a large number of subordinate phrases results in a compact and information-rich sentence that presents the reader with much more than just the main sentence. Since these long sentences cannot be properly translated into Afrikaans, definite adjustments need to be made.

The important question is: how? A long sentence follows a general line of argument, but a large amount of additional information is also added by way of subordinate phrases. If you simply break up these phrases into shorter sentences in Afrikaans, ${ }^{58}$ you might lose the flow of the argument of the Greek sentence, since subordinate phrases introduce subordinate ideas which are only loosely linked to the main sentence. The translator must continuously decide where to fit the subordinate phrases to maintain the flow of the argument. Or, to push the issue: should the translation be done in such a way that the translator "helps" the reader to follow the main line of the argument? It can be done by using phrases like: "terloops" ("by the way"), "laat ons terugkeer na die hoofargument" ("let us return to the main argument"), etc. Nida (2000:165) pointed out that

the number and length of sentences or clauses are not as important as the manner in which they relate to one another.

56 See Nida (2000:165).

57 See, as example of a long Greek sentence, Eph. 1:13-14.

58 Translators must be careful not to fall into a monotony of sentence structure, since that can be tiring (Nida 2000:165). 
When shortening sentences in the target language, one should take care to relate them in the appropriate and unambiguous ways.

Because of the nature of Greek as a language, the author of a Greek text has much more freedom to change the word order than an Afrikaans author has. This obviously means that structural possibilities become semantically more potent in Greek than in Afrikaans. To try to translate the structure of Greek to Afrikaans is to try to force a square block into a round hole. ${ }^{59}$

In light of the above, translating sentences from Greek to Afrikaans will necessarily imply the creation of different sentence structures. A new combination of the various elements in the target language must be made in an effort to get as close as possible to the suggested meaning of the source text. ${ }^{60}$ It is important to underline that in choosing new words and sentence structures, the textual and semantic constraints ${ }^{61}$ of the source language must be honoured. No unmotivated additions or omissions can be allowed. ${ }^{62}$ This applies to all the elements of the text.

\section{CONCLUSION}

Translation is a creative process in which the translator should endeavour to "combine" (mix) the different elements in such a way that the meaning in the target language comes as close as possible $e^{63}$ to that of the source language. It is important that the translator tries to produce as much of the

59 The 1933 Afrikaans translation of, for instance, Eph. 1:3ff., clearly illustrates the point.

60 In this sense, translation comes close to "retelling" the text in the receptor language, as Noorda et al. (1998:209) imply. See also Peacock (2000:202) who consequently warns against too much extra-textual interference.

61 In search of a valid constraint in translation, Sterk (1994:133-134) identifies the principal constraint as "the built-in dynamics of the oneness that exists ... between form and meaning" in the source text.

62 This is contra Reiss \& Vermeer (1984) and Nord (1991) who approach the process of translation from the needs of the receptor of the target language and allow for changes and adaptations of the source text to accommodate the requirements of the communication to the receptor.

63 Noorda et al. (1998:208) quote Croce, an Italian philosopher, who maintains that no text can really be translated. A text forms part of a larger communicative ecology in which there are delicate interrelations between many different aspects. Noorda (1998:208) remarks: "de vertaaleenheid is immers niet het word of de 'zin', maar de tekstamenhang binne een groter geheel.' 
meaning and atmosphere ${ }^{64}$ of the source text as possible. The mode in which certain feelings or ideas are expressed in the source language should accurately be transferred to the target text. ${ }^{65}$ This is a complex process, for the translator is confronted with multiple choices that must often be made with incomplete information. ${ }^{66}$ The decoding of the source text should be approached with reference to all the relevant elements that contribute to the creation of meaning. These elements should then be "translated" into the target text. It can be done by using the correct "mixture" of elements to communicate the meaning of the source text as accurately as possible in the target text. This is no mean task.

\section{BIBLIOGRAPHY}

\section{Allen K C}

www.auburn.edu/ allenkc.

BAKER M

1992. In other words: a coursebook on translation. London: Routledge.

BARTON J

1984. Reading the Old Testament: method in Biblical study. Philadelphia: Westminster.

BASTIAENS J C

1998. Een nieuwe interconfessionele bijbelvertaling voor de 21e eeuw. In: Welzen et al. 1998:149-157.

\section{BeEnTJes P}

1998. Opschriften, hoofdletters en andere manipulaties in bijbelvertalingen. In: Welzen et al. 1998:77-84.

64 "Atmosphere" is a pregnant word. What atmosphere are we talking about? Is it the original atmosphere, which includes a male-dominated, first century social and economical system? People in favour of retaining the historical character of the text will place the emphasis here. Others will argue that this is so foreign to the present day reader that it will have a negative impact on understanding.

65 See Peacock (2000:202).

66 Often the translator cannot be sure of the intention of the original author, the exact meaning of a word, the socio-cultural context, etc. 


\section{BRATCHER R G}

www.talk.religion.misc

\section{BUTH R}

2000. Aramaic Targumim: Qumran. Dictionary of New Testament Background. Downers Grove, IL: Inter-Varsity Press-CD, ad loc.

\section{CAmery-Hoggatt J} 1995. Speaking of God. Reading and preaching the Word of God. Peabody Massachusetts: Hendrickson.

\section{COMFORT P W} 1989. An analysis of five modern translations of the Gospel of John. Notes on Translation 3(3):30-55.

\section{De KRUIJF T}

1998. Interpreterende receptie. In: Welzen et al. 1998:161-169.

\section{EGGER W}

1996. How to read the New Testament. Massachusetts: Hendrickson.

\section{FORREST J N}

Literal translation. www.jayforrest.org/literal.htm.

\section{GREENSPOON L J}

Old Testament versions, ancient. Dictionary of New Testament Background. Downers Grove, IL: Inter-Varsity Press-CD, ad loc.

\section{GuTT E}

1988. From translation to effective communication. Notes on translation 2(1):2439.

\section{HENDRIKS W}

1998. Adequaat vertalen. In: Welzen et al. 1998:65-76.

\section{LARSON M C}

1984. Meaning based translation: a guide to cross-language equivalence. Lanham: UP of America.

\section{LEHMAN W}

www.egroups.com/group/bible-translation.

www.geocities.com.

\section{LOUW J P \& NiDA E A}

1989. Greek-English lexicon of the New Testament based on semantic domains. Cape Town: Bible Society of SA.

\section{NAUdé J A}

2001. Vertaalkunde vandag: 'n oorsig. Tydskrif vir Geesteswetenskappe 41(3):177194. 
NidA E A

1991. The paradoxes of translation. The Bible Translator 42(2a):5-25.

2000. Creativity in translating. In: Omanson 2000:155-166.

NidA E A \& TABER C R

1982. The theory and practice of translation. Leiden: Brill.

NoORdA S J \& BeENTJES P C (reds.)

1998. Werk in uitvoering. Haarlem: NGB.

\section{Nord C}

1991. Text analysis in translation: theory, methodology, and didactic application of a model for translation-orientated text analysis. Amsterdam: John Benjamins. 1997. Translating as purposeful activity. Manchester: St. Jerome.

\section{OMANSON R L}

1988. Can you get there form here? Problems in Bible translation. The Christian Century June:22-29.

OMANSON R L (ed.)

2000. I must speak to you plainly. Essays in honor of Robert G. Bratcher. Carlisle: Paternoster.

\section{PEACOCK H F}

2000. Extra-textual interference in Bible translation. In: Omanson 2000:201213.

Porter S E \& Hess R S (eds.) 1999. Translating the Bible: problems and prospects. Sheffield: Sheffield Academic Press.

\section{REISS K \& VERMEER H J}

1984. Grundlegung einer Allgemeinen Translationstheorie. Tübingen: Niemeyer.

\section{STERK J P}

1994. Translation as re-creation. The Bible Translator 45(1):129-139.

\section{VAN DER STICHELE J}

1998. Maar zij zei Hem en toen sprak Hij tot haar. In: Welzen et al. 1998:137148.

\section{VAN DER WATT J G}

1995. Die rol en funksie van die verskillende tipes literatuur van die Nuwe Testament in die homiletiek. In: Vos 1995:272-374.

VAN IERSEL B

1998. Vertaler en exegete als handlangers. In: Welzen et al. 1998:171-179.

\section{VAN ZYL H C}

1999. Vertalingstrategie met die oog op sinopsissamestelling. Skrif en Kerk 20(2):465-481. 
Vos C J A

1995. Die Blye Tyding. Hermeneuties-kommunikatiewe homiletiek. Pretoria: RGNuitgewers.

Welzen P H M, Dechers-Dijs M C N, Smit J F M \& VerdegaAl

C M L (reds.)

1998. Exegeten aan het werk. Vertalen en interpreteren van die Bijbel. Brugge: Tabor.

WENDLAND E R \& LOUW J P

1993. Graphic design and Bible reading. Cape Town: Bible Society of SA.

\section{WEREN W}

1998. Sporen van interpretatie in Nederlandse vertalingen van Matteüs 1,18-

25. In: Welzen et al. 1998:97-114.

WHANG Y C

1999. To whom is a translator responsible — reader or author? In: Porter \& Hess (eds.) 1999:47-49.

\section{Winckler W K \& VAN Der Merwe C H J}

1993. Training tomorrow's Bible translators: some theoretical pointers. Journal of Northwest Semitic Languages 29:41-58.

Keywords

Bible translation

Meaning

Decoding

Encoding

Socio-cultural ecology

Genre

Paradigmatic cohesion 